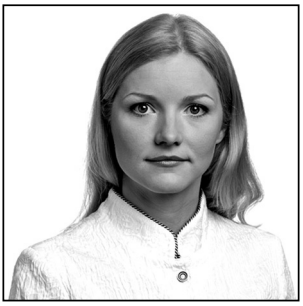

Katri Paas-Mohando ${ }^{* 1}$

PhD, Adjunct Lecturer, University of Tartu

Senior Associate at LAWIN Tallinn

\title{
Extraterritorial Merger Control Enforcement in Small Economies-Challenges and Possibilities
}

\section{Introduction}

It has been widely acknowledged that, while mergers of undertakings can expand markets and bring benefits to the economy, some mergers may reduce competition to an undesirable extent. Therefore, many states, around the globe, have enacted merger control regimes to prevent the emergence of anti-competitive market structures. It is typical that merger control rules require that merging parties notify a competition authority of their transactions before their implementation, whereupon the authority may prohibit the merger or impose conditions on the merging parties if the merger causes competition concerns.

In principle, any state may require the notification of whichever mergers it wishes (whether domestic or involving foreign undertakings) or prohibit the same. States may also take enforcement actions within their boundaries, but their orders with respect to foreign undertakings generally remain 'toothless' abroad, where no mechanism for enforcement can be applied. Hence, exercising effective control over extraterritorial mergers poses challenges to all states.

From the perspective of national competition authorities, four types of merger situations can be distinguished: i) domestic mergers, wherein all firms concerned have their seat within the state of the authority; ii) foreign mergers, wherein the firms concerned have their seat in one and the same foreign state; iii) international mergers, wherein one of the firms concerned is foreign and the other has its seat in the state of the authority; and iv) foreign international mergers, wherein the companies concerned have their seat in two (or more) foreign states. ${ }^{*}$

Small economies are confronted with foreign, international, and foreign international mergers more often than are larger economies. ${ }^{*}$ At the same time, their power of enforcement, to give effect either to their

1 The article is based on the author's doctoral thesis Implications of Smallness of an Economy on Merger Control, available at http://dspace.utlib.ee/dspace/bitstream/handle/10062/10282/Paaskatri.pdf?sequence $=1$ (most recently accessed on 23.5.2014). The author thanks Michal S. Gal, Rosa Greaves, and Michael Steinicke for their useful comments and Paul Varul and Olav Kolstad for excellent supervision. All errors and omissions remain my own.

2 Walter A. Stoffel. International mergers: Merger in small economies. - Annual Proceedings of the Fordham Competition Law Institute: International Antitrust Law \& Policy, Fordham Competition Law Institute, Juris Publishing, Inc. 2007, p. 323 .

$3 \quad$ Ibid., p. 323 . 
notification requirements or to any later merger prohibition, could be rather limited ${ }^{*}$, as is exemplified below. Therefore, enforcement issues tend to be particularly topical for small economies.

Hence, the aim of this article is to seek ways in which small economies could enhance their enforcement possibilities in cases of foreign, international, and foreign international mergers causing competition problems in said small economy. The article suggests that within the EU the competition authorities of small states facing enforcement issues could benefit from the EU Merger Regulation (EUMR) referral regime. This article could be of interest for competition authorities of small economies in the EU but also for policymakers in other free-trade areas, who might find it appropriate to consider creating a similar system elsewhere.

Proceeding from the aim described, the article is presented in three parts. Firstly, it discusses the problems of small economies with regard to extraterritorial merger control enforcement (in Section 2). Then, in Section 3, it considers various traditional measures, such as co-operation and comity, as means to enhance the enforcement position. Finally, it describes the enforcement options within the EU both under various enforcement regulations and under the EUMR referral regime (in Section 4).

\section{The position of small economies with regard to enforcement of merger control}

From the perspective of small economies, the enforcement concerns are especially evident in the case of mergers of large multinational firms. If the merging parties are not seated in the small economy that is affected by the merger, the actual bargaining and enforcement power of the competition authorities of the small economy vis-à-vis such market players is often rather limited. ${ }^{*}$

While large economies could enforce their rules by creating obstacles to operations of foreign undertakings that disregard a merger prohibition or fail to comply with the notification requirements in their jurisdiction (e.g., seizure of assets or suspension of operation licences), this tactic is unlikely to yield a satisfactory outcome for small economies. The main problem is that small economies can rarely make a credible threat to prohibit a merger of foreign undertakings. Given that trade in the small economy usually accounts for only a small portion of the foreign undertaking's total world operations, if the small jurisdiction places significant restrictions on the merger, the foreign undertaking would most likely choose to exit the small economy and trade only in other jurisdictions. Such enforcement issues have been recognised by the members of the International Competition Network. ${ }^{* 6}$

This situation is well exemplified by the Unilever / Ben \& Jerry's (2000) case, from the practice of the Israel Antitrust Authority. The matter had to do with the acquisition of US ice-cream company Ben \& Jerry's by the Anglo-Dutch multinational consumer-goods company Unilever. The merger was subject to control, inter alia, in Israel, whose competition authority identified competition concerns in the Israeli ice-cream market. The merger was cleared conditionally, after the parties undertook to distribute Ben \& Jerry's ice cream through an independent distributor who would be free to determine the prices charged for the products. Moreover, the competition authority required that the quality and quantity of the products be at least as high as it had been before the merger and that any new product be made available to the independent distributor. ${ }^{*}$ Even though such behavioural remedies are generally considered weak options for alleviation of competition concerns, ${ }^{* 8}$ no better options could be found for the competition authority in this case.

This case shows clearly the difficult trade-offs that the competition authorities of small economies often face in the event of foreign international mergers, as the actual choice of measures is rather limited. Had

4 Competition Law Forum: 'Small economies and competition policy-a fair deal?', summary of conference presentations and discussions in Luxembourg, October 2007.

5 Michal S. Gal. Competition Policy for Small Economies. Cambridge, Massachusetts, and London: Harvard University Press 2003, pp. 244-246.

6 ICN Special Project for the 8th Annual Conference, 'Competition Law in Small Economies', prepared by the Swiss Competition Commission and Israel Antitrust Authority, 2009. Available at http://www.internationalcompetitionnetwork.org/uploads/ library/doc385.pdf (most recently accessed on 23.5.2014), p. 33.

7 Conditions for the approval of the merger between Ben \& Jerry's Homemade, Inc. and Unilever NV, cited through Gal (see Note 5), p. 246.

8 For more on this, see Katri Paas. Implications of the smallness of an economy for merger remedies. - Juridica International XV (2008), pp. 94-103. 
the merger been prohibited by the competition authority, there would have been a great risk that, instead of withdrawing from the transaction, the merging parties would have simply chosen to cease their activities in Israel. This would have been even more detrimental for the Israeli consumers than the anti-competitive merger. As noted by Michal S. Gal, small economies are often left only to rely on the assumption that international firms will not change their strategic decisions (such as Ben \& Jerry's introduction of new products in the world market in this case) only to reduce competition in the small economy." ${ }^{* 9}$

The above-described conundrum is highlighted also by the economic rationale according to which a foreign undertaking would exit the small economy if its loss of revenue from terminating its trade there would be smaller than the increase of revenues it anticipates as a result of the proposed merger elsewhere. At the same time, the negative welfare effects of the foreign undertaking's exit from the small economy may well be greater than the negative welfare effects of the continued operation of the merged entity within its borders. Accordingly, a small economy usually does not have an incentive to prevent the undertaking from trading within its borders if it did execute the relevant merger. Aware of this consideration, foreign undertakings are unlikely to take into account the effects of their merger on a small economy. They instead consider only the effect of the merger on their own profits in such markets. ${ }^{* 10}$

If a merger of large international undertakings has significant anti-competitive effects in various countries, including, for instance, neighbouring larger jurisdictions, it is likely to be prohibited or subjected to remedies by other countries' authorities, and the merger will not take place in the small economy either (or, if remedies are applied, the competition concerns would be resolved). Therefore, small economies can rely on the merger control of larger economies to a certain extent. However, this can only provide a partial solution, because the larger economies focus on the effects of the merger on their markets, and the effects of any given merger on the small economies may be different and more adverse. Moreover, the enforcement foci may differ between jurisdictions. Merger control regimes could pursue various, possibly differing, goals; and efficiency or industrial policy considerations could be taken into account to differing extent. Furthermore, if the merger control of a larger neighbour favours 'national champions' and permits an otherwise anti-competitive merger on this basis, there is little gain for the small economy, which would suffer from the anti-competitive effects of the merger in its markets.

Hence, different states claiming jurisdiction over a merger may have different or even competing goals. If the larger jurisdiction hosting the merging undertakings clears a merger that should, from a small economy's perspective, be prohibited, there is little left for the small economy to regulate. Depending on the circumstances of the case, local remedies could perhaps be applied to rectify the situation in part, but it is unlikely that the larger economy that has cleared the merger would be keen on assisting the smaller jurisdiction to enforce its prohibition. The situation could also be the opposite: a merger might be prohibited by a large jurisdiction but cleared in a small one. In such cases, either the small economy's clearance would remain unused by the merging parties, in the event that they decide to abort the merger upon the large jurisdiction's prohibition, and the pre-merger situation would remain; or the merging parties could decide to implement the merger only in limited scope with respect to activities in the small economy.

There have been voices among practitioners stating that small economies are 'overly paranoid' about their inability to enforce their merger regimes. Large undertakings are generally not prepared to run the reputation risk of being found to have breached a regulatory requirement. Therefore, companies follow the notification requirements of large and small states equally. ${ }^{* 11}$ The author's experience generally is consistent with this observation. However, while complying with the notification requirements does not generally pose significant problems, particularly where the merger is unlikely to cause competition concerns, the situation could prove different in truly problematic cases.

Therefore, the following section analyses the means that can be employed to overcome enforcement problems, firstly by looking at the issues from a more traditional international perspective, after which the same issues are discussed within the context of the EU system.

9 Gal (see Note 5), p. 246.

$10 \quad$ Ibid., pp. 242-243; OECD Policy Roundtables: Cross-Border Merger Control: Challenges for Developing and Emerging Economies, 2011. Available at http://www.oecd.org/daf/competition/mergers/50114086.pdf (most recently accessed on 23.5.2014), p. 343 .

11 Speech by James Webber at the Competition Law Forum: 'Small economies and competition policy-a fair deal?', in Luxembourg, October 2007. 


\section{International co-operation and comity as means to enhance merger control enforcement}

Faced with globalisation of the economy and with the problems of the application and enforcement of merger control rules, international co-operation is gaining increased attention. In pursuit of means to introduce consistent rules and to enhance extraterritorial enforcement, major trading partners have concluded agreements, most of them bilateral at present. ${ }^{*} 2$ Such agreements adopt positive comity principles targeted at tackling a 'common evil' when there is a predisposition to co-operation and to overcome the problem of non-enforcement by foreign jurisdictions. However, comity principles have limited effect when the merger policy principles adopted by the co-operating jurisdictions differ from one another ${ }^{*} 13$ or where merger control principles do not take into account the effects of the proposed merger on foreign jurisdictions.

In addition to co-operation agreements, there have been initiatives established from various international platforms aimed at increasing co-operation in the field of competition law. ${ }^{*} 4$ However, all rules adopted within such frameworks are purely voluntary and non-binding.

Hence, at this stage, the multilateral platforms do not involve operation of any solid extraterritorial enforcement framework as could resolve small economies' merger control related enforcement problems.

\section{Enforcement within the EU-a solution for small Member States?}

\subsection{Enforcement of the European Commission's decisions}

The EUMR grants the European Commission a rather extensive toolkit for enforcing merger control rules. It may prohibit a merger under Article 8 (3), but it also may give conditional permission under Articles 6 (2) and 8 (2). Furthermore, where the Commission finds that a merger already implemented is anti-competitive or a merger has been implemented in contravention of a condition attached to a clearance decision, it may order the merger to be dissolved under Article 8 (4) or. take any other measure appropriate for restoring the pre-merger situation as fully as possible.

If the merging undertakings do not obey the merger notification requirements or the Commission's decisions, the Commission may impose rather heavy fines or periodic penalty payments on the merging undertakings as set out in Articles 14 and 15 of the EUMR, respectively. The Commission's decisions imposing pecuniary sanctions must be enforced pursuant to Article 299 of the Treaty on the Functioning of the European Union (TFEU) in the same manner as national judgements in the Member State where the Commission seeks enforcement without any further recognition or other procedures. Hence, the enforcement of the Commission's decisions is rather straightforward and well secured.

12 The best known bilateral agreement regarding the application of competition laws has been in place between the EU and the US for decades, since 1991. Further to this development, many bilateral and multilateral antitrust co-operation agreements have been concluded between and among various states, around the globe. For more information, see Jonathan Galloway. Moving towards a template for bilateral antitrust agreements. - World Competition 28 (2005)/4, pp. 589-614.

13 Mads Andenas, Anestis Papadopoulos. Antitrust law and international companies. - European Business Law Review 12 (2002)/3, p. 201.

14 United Nations Conference on Trade and Development (UNCTAD) adopted the Set of Multilaterally Agreed Equitable Principles and Rules for the Control of Restrictive Business Practices in 1980, and the Organisation for Economic Co-operation and Development (OECD) adopted its Recommendations and Best Practices in 1965 (with revisions in 1995). There have also been attempts to establish an international competition law regime within the WTO, but, after years of unsuccessful negotiations, this idea was abandoned in 2004. In another development, in 2001, various competition authorities, from all over the world, established the International Competition Network (ICN), which is a good forum for work toward soft-law harmonisation; however, it does not amount to enforcement co-operation in specific cases. 


\subsection{Enforcement by Member States}

Various steps have been taken to facilitate the enforcement of court decisions both on civil ${ }^{* 15}$ and on criminal matters ${ }^{* 16}$ within the EU and beyond. However, in most jurisdictions, merger control related infringements constitute administrative or quasi-criminal violations, usually not civil matters or criminal offences. Therefore, most of these legal instruments do not apply in cases of merger control related decisions.

Even though the framework decision pertaining to mutual recognition of financial penalties provides for the mutual recognition of financial penalties imposed by both the judicial and administrative authorities of another Member State, it still does not resolve the merger control enforcement issues. This is because of the 'double criminality rule', according to which the executing state may make its recognition and execution of a decision of an issuing state subject to the condition of the decision being related to conduct that would constitute an offence under the law of the potentially executing state. ${ }^{* 17}$ This may not be the case with all merger control related violations.

Therefore, if a Member State is seriously concerned about the effects of a merger in its territory and finds difficulty in enforcement against undertakings of another Member State, it is worthwhile to consider resorting to the merger control referral mechanism discussed below, because this would enable subjecting the merger to review by the European Commission, whose decision can be enforced by virtue of Article 299 of the TFEU.

\subsection{Division of jurisdiction between the European Commission and national authorities}

\subsubsection{Division of jurisdiction and referral mechanisms under the EUMR}

Article 21 of the EUMR establishes a 'one-stop shop' principle according to which mergers with a 'Community dimension'-i.e., those above the turnover thresholds set forth in Article 1 of the EUMR-fall within the exclusive jurisdiction of the Commission, with Member States being precluded from applying national merger control rules to such mergers.

The general division of jurisdiction between the Commission and national competition authorities is an expression of the subsidiarity principle, which is embodied in Article 5 Treaty on European Union (TEU). ${ }^{* 18}$ In this light, it is presumed that the Commission is a suitable entity for action with respect to mergers with a Community dimension. The high level of the thresholds is meant to imply the intended transaction having an effect in several Member States and therefore being most appropriately assessed in a uniform way by the Commission. ${ }^{*}{ }^{*}$ The possibility of re-attributing jurisdiction by using referral mechanisms provides some flexibility to this presumption.

Transactions involving undertakings from small economies are only rarely subject to control by the Commission. This does not mean, however, that mergers between undertakings from small economies do not have effects in several (small) Member States. The Commission seems to have recognised this, and, therefore, in the course of reform of the EUMR, adjustment of the Community dimension thresholds was debated. ${ }^{* 20}$ While the thresholds for having a Community dimension remained unchanged, the referral

15 Council Regulation (EC) No. 44/2001 of 22.12.2000 on jurisdiction and the recognition and enforcement of judgments in civil and commercial matters, OJ L 12, 16.1.2001, pp. 1-23.

16 There are various examples: ibid.; Council Framework Decision 2003/577/JHA of 22.7.2003 on the execution in the European Union of orders freezing property or evidence, OJ L 196, 2.8.2003, pp. 45-55; Council Framework Decision 2005/214/JHA of 24.2.2005 on the application of the principle of mutual recognition to financial penalties, OJ L 76, 22.3.2005, pp. 16-30; Council Framework Decision 2006/960/JHA of 18.12.2006 on simplifying the exchange of information and intelligence between law enforcement authorities of the Member States of the European Union, OJ L 386, 29.12.2006, pp. 89-100.

17 The framework decisions cover offences established by the issuing state and serving the purpose of implementing obligations arising from instruments adopted under the TFEU. This would enable an issuing state to require the recognition and enforcement of financial penalties imposed on undertakings for competition-law violations infringing Articles 101 and 102 of the TFEU, even if such violations do not constitute qualifying offences in the executing state. However, since neither the TFEU nor any instruments adopted under it require Member States to establish a national merger control regime, infringements of national merger control rules are not covered by the framework decisions.

18 Mark Furse. The Law of Merger Control in the EC and the UK. Oxford and Portland, Oregon: Hart Publishing 2007, pp. 51-52.

19 Franz J. Säcker et al. Competition Law: European Community Practice \& Procedure. London: Sweet \& Maxwell 2007, pp. 2300-2301.

20 Commission Green Paper on the Review of Council Regulation (EEC) No. 4064/89, p. 29; Francisco E.G. Díaz. The reform of European merger control: Quid novi sub sole? - World Competition 27 (2004)/2, p. 178. 
mechanisms were revised-pre-notification mechanisms were introduced and the existing post-notification referral conditions were loosened. ${ }^{{ }^{2} 1}$

In consequence of the reforms, the current EUMR provides four case referral mechanisms, in Articles 4 (4), 4 (5), 9 and 22. The table below summarises the distinctive features of the mechanisms envisaged in each of the mentioned EUMR articles (or sections thereof).

Table 1: Summary of referral mechanisms under the EUMR

\begin{tabular}{|l|l|c|c|c|c|}
\hline EUMR article: & Pre-notification & $4(4)$ & $4(5)$ & 9 & 22 \\
\hline \multirow{2}{*}{ Timing } & Post-notification & $\times$ & $\times$ & & \\
\hline \multirow{2}{*}{ Referral applicant } & Merging undertakings & & & $\times$ & $\times$ \\
\hline & Commission or Member State & $\times$ & $\times$ & & \\
\hline \multirow{2}{*}{ Direction } & From Commission to Member State & $\times$ & & $\times$ & \\
\hline & From Member State to Commission & & $\times$ & & $\times$ \\
\hline
\end{tabular}

Articles 4 (4) and (5) allow merging firms to apply for referral either of a merger that is subject to the Commission's merger control to one or several Member States' control (in Article 4 (4)) or of a merger that is subject to control by one or several Member States to the Commission's control (Article 4 (5)). The application for such referral can be made prior to the notification of the transaction to the authority (or authorities) having the original jurisdiction. After this, the authorities concerned may either approve or disapprove the referral.

Articles 9 and 22 provide for post-notification referral, which can be applied for by either the Commission or any Member State but not by merging firms. Under Article 9 (2), the Commission may refer a merger to one or more Member States if both of the following legal requirements are met:

(i) the merger affects competition in a market

(ii) the market in question is within the requesting Member State, presents all the characteristics of a distinct market, and does not constitute a substantial part of the common market

It is possible to refer the whole transaction or only part of it to one or more Member States. ${ }^{* 2}$ As is noted above, Member States may request referral also on their own initiative. Having received a referral request from the Commission, Member States may either approve or reject the request. ${ }^{*} 3$

From the perspective of competition authorities of small economies Article 22 is the most relevant. Under Article 22 (1) one or more Member States may request the Commission to examine any merger that does not have a Community dimension, if the following two legal requirements are met:

(i) the merger 'affects trade between Member States'

(ii) the merger 'threatens to significantly affect competition within the territory of the Member State or States making the request'

The request can be made by a Member State alone or by Member States jointly, and any other Member State may later join the initial request made by one Member State. ${ }^{* 24}$ If the Commission accepts the request, the Member State(s) having made the request may no longer apply its/their national legislation to the merger, while Member States that have not joined the request can continue controlling the merger under their national rules. ${ }^{*} 5$

In the author's view, the Article 22 referral mechanism should be able to alleviate merger control enforcement concerns of small EU member states. Accordingly, the conditions for resorting to Article 22 referral are examined in more detail below.

21 Werner Berg. The new EC merger regulation: A first assessment of its practical impact. - Northwestern Journal of International Law \& Business 24 (2004)/3, p. 683.

22 EUMR, Article 9 (3).

23 EUMR, Article 9 (6).

24 EUMR, Article 22 (2).

25 EUMR, Article 22 (3), Commission Notice on case referral in respect of concentrations, OJ C 56, 5.3.2005, pp. 2-23, Section 50. 


\subsubsection{Opportunities under Article 22 of the EUMR}

\subsubsection{Legal requirements for application of Article 22}

As indicated above, Article 22 (1) sets out two main substantive legal requirements that must be met for application for a referral. Firstly, the merger should affect trade between Member States.

According to the standard test developed by the European Courts, the notion 'may affect' implies that it must be possible to foresee with a sufficient degree of probability, on the basis of a set of objective factors of law or fact, that the matter may have an influence on the pattern of trade between Member States. Even though such court practice is developed with respect to application of Articles 101 and 102 of the TFEU, the Commission has indicated that this practice can be applied to interpretation of the referral conditions of Article 22 of the EUMR by way of analogy. ${ }^{*}{ }^{26}$ The Commission Notice 'Guidelines on the effect on trade concept ${ }^{{ }^{*} 27}$ provides a good overview of the relevant criteria. In practice, wider than national relevant markets could also be a factor in argument that the 'affect trade between Member States' criterion is satisfied.

The Canon/IRIS merger case ${ }^{* 28}$ from the Commission's practice serves as an example of how the Commission evaluates this criterion. The case had to do with the acquisition of Belgian office automation equipment provider I.R.I.S. by a Japanese provider of imaging and other electronic equipment, Canon. The review of this transaction was referred to the Commission by the Belgian competition authority, which was subsequently joined by the national competition authorities of Austria, France, Ireland, Italy, Portugal, and Sweden. In the decisions related to the referral under Article 22, the Commission noted that the transaction would affect at least the market for portable document scanners. Given the low transport cost, the absence of region-specific technical requirements, and similar market conditions (including the presence of the same suppliers throughout the EEA), the relevant geographic market was likely EEA-wide in scope. This statement was consistent with the Commission's earlier practice. From this basis, the Commission was satisfied that the referral request showed to the requisite legal standard that the transaction affected trade between Member States.

The second legal requirement prescribes that, for the request to be honoured, the merger should threaten to affect competition significantly within the territory of the Member State(s) making the request. ${ }^{* 29}$ The referring Member State(s) should demonstrate that based on a preliminary analysis there is a real risk that the transaction may have a significant adverse impact on competition and, therefore, that it deserves close scrutiny. ${ }^{*} 30$ Such risk is considered sufficient to satisfy this criterion. ${ }^{*} 31$

In the referred Canon/IRIS case, the Commission pointed out that the request from the Belgian competition authority explained that the proposed transaction threatened to have a significant effect on competition in the market for portable document scanners in Belgium and also in other Member States. The Belgian competition authority had highlighted that the proposed transaction would lead to a high post-merger market share of the merged entity and further increase the concentration in an already oligopolistic market. The combined share of the merging undertakings amounted to more than $50-60 \%$ in the EEA by both value and volume and exceeded $70-80 \%$ for both in Belgium. The increment in market share was over $30-40 \%$ in Belgium and around 10-20\% in the EEA in terms of both value and volume. Even though the merging undertakings submitted that the market data used by the Belgian competition authority did not accurately reflect the size of the market for portable document scanners (since the sales of a significant number of competitors had not been included), the Commission found that verifying the validity of this argument required further market investigation. In addition, in light of a comparison of the characteristics and prices of the two companies' respective product ranges, the Belgian competition authority considered Canon and I.R.I.S. to be each other's closest competitors. It was also pointed out that the most important remaining competitor, Fujitsu, was not competitive in the relevant sub-market.

26 Ibid., Section 43.

27 Commission Notice - guidelines on the effect on trade concept contained in Articles 81 and 82 of the Treaty, OJ C 101, 27.4.2004, pp. 81-96.

28 Commission decision of 18.2.2013, Case COMP/M.6773 - Canon/IRIS. Decisions related to referral were dated 26.11.2012.

29 EUMR, Article 22 (1).

$30 \quad$ Notice on case referral (see Note 25), Section 44.

31 F.J. Säcker et al. (see Note 19), p. 2459; Trevor Soames, Sylvie Maudhuit. Changes in EU merger control: Part 1. - ECLR 26 (2005)/1, p. 63. 
Hence, the Commission concluded that a prima facie assessment indicated that the transaction could give rise to serious competition concerns with respect to the supply of portable document scanners within the EEA and considered this transaction to satisfy the legal requirements for Article 22 referral.

Taking into account the foregoing considerations, the Commission accepted the referral and carried out a full merger control investigation of the matter. Even though the Commission ultimately cleared the merger, because it found that the merged entity would continue to face competition from a number of other strong competitors both in the EEA and in individual Member States, the case serves as a good example as a case wherein a small Member State's referral request could have led to a potentially problematic case being subjected to the Commission's review. Had the Commission found after full investigation that the merger indeed raised competition concerns, it could have prohibited the merger or imposed remedies on the merging undertakings, with enforcement of the Commission's decision having been effectively secured by Article 299 of the TFEU.

\subsubsection{Other considerations related to application of Article 22}

In addition to the legal requirements set out in Article 22 (1), the Commission indicated in its Notice on case referral that there are two categories of cases that it considers most appropriate for referral to the Commission pursuant to Article 22:

(i) cases which give rise to serious competition concerns in one or more markets which are wider than national in geographic scope, or where some of the potentially affected markets are wider than national, and where the main economic impact of the merger is connected to such markets;

(ii) cases which give rise to serious competition concerns in a series of national or narrower than national markets located in a number of Member States, in circumstances where coherent treatment of the case (regarding possible remedies, but also, in appropriate cases, the investigative efforts as such) is considered desirable, and where the main economic impact of the merger is connected to such markets. ${ }^{*} 2$

In such cases, the Commission's powers of investigation and remedial and enforcement action are more appropriate than the more limited means available to the Member States. Therefore, the Commission's competence would be in line with the subsidiarity principle, since it represents the most effective means of avoiding the creation of obstacles to further European integration. ${ }^{*} 3$

The Canon/IRIS case fell into the first of the above-mentioned categories, because the markets concerned by the merger were broader than national. However, from the small Member State's perspective, a case might be suitable for referral also where the markets are national or narrower than national, if that merger has an impact, for instance, for several small (neighbouring) Member States, since it could then be deemed to fall into the second category of cases.

In practical terms, for ascertaining of whether a case is suitable for referral to the Commission, some further aspects should be borne in mind. Firstly, the transaction must qualify as a 'concentration' within the meaning of Article 3 of the EUMR, and it should not have a Community dimension. ${ }^{*} 34$ Hence, minority acquisitions falling short of control do not qualify. At the same time, it is not a requirement that the merger be subject to control under the national merger control thresholds, as long as the other necessary conditions of Article 22 are satisfied. ${ }^{*} 5$ Moreover, a Member State may apply for a referral even in circumstances wherein the merger, because it did not meet the national notification thresholds, has been lawfully implemented though not cleared under national law, when that merger has a significant effect on trade between Member States. ${ }^{*} 36$

This aspect of the Article 22 referral mechanism could prove rather helpful and significant for small Member States, because it may provide an option of expanding the scope of merger control in some specific cases. In the author's practical experience, it is often the case that international undertakings choose not to have their own sales enterprises or distributors in all countries and instead use one or several regional

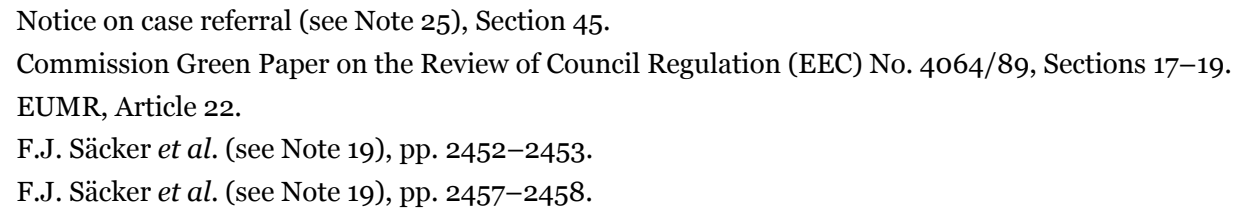


distributors for supplying their goods and handling customer relations in smaller markets. In such cases, the national merger control turnover thresholds for the merging undertakings might not be exceeded, since the undertakings in question do not have direct turnover in the smaller Member States concerned and, hence, the merger may escape merger control in such a small state. At the same time, the merger may still have significant effect on the competition conditions in the small Member States concerned. Accordingly, Article 22 could be used by Member States confronted with such particular circumstances for purposes of subjecting mergers of this nature to the European Commission's review.

Secondly, it is important to bear in mind that the referral request must be made within 15 working days of the date on which the merger was notified, or if no notification is required, otherwise made known to the Member State concerned. ${ }^{*} 37$ This criterion is a formalistic one and there is no reason why a small Member State should not be able to comply with it, if it finds out a merger which may raise serious competition concerns for it.

Finally, the Commission has indicated that it will also balance various interests-as the referral may entail additional cost and delay for the merging undertakings, referrals should normally be limited to those cases wherein a real risk appears to present itself of negative effects on competition and trade between Member States, and where it appears that these would be best addressed at the Community level. ${ }^{*} 8$

\subsubsection{Assessment of the suitability of Article 22 referrals as a means to foster merger enforcement for small Member States}

From the above, it does not appear that the Article 22 referral conditions are overly burdensome for Member States seeking a referral, provided that the Commission is, in fact, willing to take jurisdiction in practice. Proving cross-border effects should not pose many hurdles where the merger involves foreign undertakings but has significant effects in the small economy. Showing such effects may be more problematic if the merger involves domestic undertakings, but enforcement is not problematic in such cases, at least with respect to extraterritoriality problems, and no referral is necessary.

As of 30 April 2014, there had been, in total, 31 referral requests made under Article 22, of which the Commission had refused only four cases. ${ }^{*}{ }^{39}$ Numerous Article 22 referrals have led to rather heavy scrutiny by the Commission. For instance, in the case Kesko/Tuko, involving an already consummated merger between two Finnish undertakings operating mainly in the daily consumer-goods sector, the Finnish competition authority referred the transaction to the Commission at a time when no merger control was in place in Finland. The Commission found that, in consequence of the transaction, Kesko would have gained a dominant position in the Finnish retail markets for daily consumer goods and for cash-and-carry sales of daily consumer goods, which would have significantly impeded effective competition in those markets. The Commission also found that the transaction would have affected inter-state trade through its influence on the importation of daily consumer goods into Finland and the creation of barriers to entry for potential competitors from other Member States. Therefore, the Commission declared the merger incompatible with the common market and required its dissolution. ${ }^{*}{ }^{40}$ When one looks at the decisional practice of the Commission, it can be concluded that most of the cases that the Commission has reviewed further to Article 22 referral have been serious enough to be dealt with in Phase 2 and/or have been cleared only conditionally, with commitments being imposed. ${ }^{*}{ }^{4}$

It cannot be overlooked that the application of Article 22 has not been entirely seamless and has gathered some criticism from practitioners, especially because of delays and added costs for merging

37 EUMR, Article 22 (1).

38 Notice on case referral (see Note 25), Section 45.

39 See the Commission's merger control statistics, available at http://ec.europa.eu/competition/mergers/statistics.pdf (most recently accessed on 23.52014 ).

40 Commission Decision of 20.11.1996, Case IV/M.784 - Kesko/Tuko. Similarly, the Commission found that the acquisition by Blokker, a major retail operator in the Netherlands, of the Dutch operations of Toys R Us, one of the world's biggest toy retailers, strengthened a dominant position in the market for specialist toy-retail outlets in the Netherlands, as a result of which effective competition was significantly impeded, and declared the transaction incompatible. It imposed divestiture orders on the merging firms (see Commission Decision of 26.6.1997, Case IV/M.890 - Blokker/Toys " $R$ ” Us).

41 See the summary table of Article 22 referrals as of 2011 in Gianni De Stefano et al. Merger referrals in practice - analysis of the cases under Article 22 of the Merger Regulation. - Journal of European Competition Law \& Practice 2 (2011)/6, pp. 537-550. - DOI: http://dx.doi.org/10.1093/jeclap/lpro74. 
undertakings. ${ }^{* 2}$ However, such shortcomings do not reduce its value as a means to resolve merger-control enforcement problems for small economies in the EU in the case of mergers having anti-competitive effects. Of course, Article 22 cannot solve such problems for small economies outside the EU. However, the EU merger control regime and its referral system could serve as an example for other free-trade areas (such as Mercosur, the Andean Community of Nations (CAN), and ASEAN).

\section{Conclusions}

The recognition of a state's extraterritorial jurisdiction depends to a large extent on the good will of the undertakings concerned by the state's enforcement actions and on their home states' willingness to recognise the enforcement action of the other state. Furthermore, hindering the activities of foreign undertakings that disregard merger prohibition or that fail to comply with the notification requirements is also unlikely to provide satisfactory outcomes for small economies. Therefore, small economies are in a weak position in enforcing their merger control. In some instances, small economies may benefit from the merger control undertaken by large economies, but the interests of small and large economies in controlling a merger do not necessarily always coincide.

As currently applied, the traditional measures in international law, such as co-operation and comity, do not provide much help in addressing small economies' enforcement issues. However, the referral mechanism contained in Article 22 of the EUMR, which allows for referring a merger lacking a Community dimension to the Commission's control, could provide solutions for small EU member states when a merger has significant anti-competitive effects but the competition authority is concerned about the enforcement possibilities.

42 See, for example, Juan Rodriguez. Merger referrals. Available at http://globalcompetitionreview.com/reviews/47/sections/162/chapters/1818/ (most recently accessed on 23.5.2014); Jens Peter Schmidt, Isabel Simon. Referrals of merger control cases to the European Commission: Too much flexibility to the detriment of companies? -Mayer Brown Legal Update, 23 June 2011, available at http://www.mayerbrown.com/publications/referrals-of-merger-control-cases-to-the-european-commission-too-much-flexibility-to-the-detriment-of-companies-06-23-2011/ (most recently accessed on 23.5.2014). 